\title{
TINGGALAN-TINGGALAN ISLAM DI MAJENE SULAWESI BARAT
}

\author{
The Relics of Islam in Majene, West Sulawesi
}

\begin{abstract}
Idham
Balai Penelitian dan Pengembangan Agama Makassar

Jl. A.P. Pettarani No. 72 Makassar

Email: idbodi@yahoo.co.id

Naskah diterima tanggal 21 Agustus 2012. Naskah direvisi tanggal 7 September 2012. Naskah disetujui tanggal 2 Januari 2013

Abstrak

Penelitian ini merupakan penelitian eksploratif. Penelitian penjajagan dalam arkeologi merupakan penelitian awal dari suatu obyek. Hasil penelitian penjajagan ini menemukan masih adanya situs-situs di Majene, Sulawesi Barat, berupa bagunan masjid purbakala di Salabose, serta empat buah makam penyiar Islam pertama di Majene. Selain itu, penelitian ini juga menemukan adanya naskah-naskah klasik berupa Alquran tulisan tangan, naskah khutbah, dan bendera.
\end{abstract}

Kata kunci: masjid kuna, makam penyiar Islam, naskah klasik

\begin{abstract}
The research is the exploratory study in which it is the preliminary research of an object in archeology. Based on the results, the researcher found the persistence of the archeological sites in Majene, West Sulawesi, namely the ancient mosque in Salabose, and the four graves of the early Islamic propagators in Majene. In addition, the research also found the classical texts in the forms of handwritten Quran, Islamic preaching text, and flag.
\end{abstract}

Keywords: the ancient mosque, the graves of the early islamic propagators, classical texts

\section{PENDAHULUAN}

$\mathrm{P}$ roses islamisasi di Nusantara merupakan salah satu obyek riset yang paling tinggi nilai atraktifnya, baik dari kalangan IndonesianisIslamolog yang notabene ilmuwan asing, maupun kalangan ilmuwan domestik dilihat dari karya intelektual mereka yang dilempar ke ranah publik. Dengan memanfaatkan filsafat, metode dan setting riset yang berbeda-beda berimplikasi pada temuan, dan teori yang diformulasikan sebagai artikulasi hasil penelitian mereka.

M.C. Ricklefs sebagaimana dikutip Ahmad Sewang mendeskripsikan islamisasi sebagai suatu proses yang tidak pernah berhenti, "Islamisation is a process which has continued down to the present day" (Sewang, 2005: 5). Islamisasi yang berlanjut hingga kini dapat diklasifikasi dalam beberapa fase sebagaimana yang diformulasikan oleh J. Noorduyn yang membagi proses islamisasi untuk domain Sulawesi dalam tiga tahap. Pertama, sejak datangnya (de komst) agama Islam, yaitu datangnya orangorang Islam untuk pertama kalinya di suatu daerah. Kedua, penerimaan (receptie) agama Islam, berarti penduduk setempat telah memeluk agama Islam. Ketiga, penyebaran (uitbreiding) agama Islam, yaitu setelah Islam mulai disebarkan ke dalam masyarakat atau disebarkan ke luar daerah di mana Islam pertama kali diterima (dalam Sewang, 2005).

Islamisasi dapat dipetakan dalam beberapa domain. Pertama, dengan penerimaan Islam melalui konversi dengan jalan perpindahan agama atau kepercayaan yang dianut sebelumnya kepada agama Islam, pola penerimaan Islam yang demikian (dalam konteks islamisasi di Sulawesi) menurut analisis Sewang diawali oleh penduduk yang tinggal 
di pesisir pantai dan berangsur-angsur merambah wilayah pedalaman. Kedua, islamisasi melalui jalur politik, yang disebut secara spesifik sebagai tahap pertumbuhan kerajaan-kerajaan Islam. Islamisasi melalui pola ini tidak terlepas dari peranan raja di kerajaan-kerajaan tersebut, jika gubernur dan para bangsawan menerima agama baru, rakyat akan siap mengikuti, karena dalam adat mereka, dalam tingkat yang berbeda-beda, para raja atau sultan dipandang sebagai wakil dari Tuhan di dunia. Ketiga, tesis Sewang dengan mengajukan pola sosial budaya, yaitu perubahan yang terjadi secara adaptif atau penyesuaian secara bertahap dari budaya praislam kepada agama Islam, para muballig Islam tidak melakukan perombakan pranata sosial-budaya yang sudah ada, melainkan mereka memberi nilainilai Islam pada pranata lama atau menambahkan dengan pranata baru yang berasal dari budaya Islam (Sewang, 2005: 80).

Abdul Hadi WM mengemukakan bahwa penyebaran Islam di Nusantara berlangsung setidaktidaknya dalam tiga pola. Pertama, pola integratif yang berlaku di kepulauan Melayu (termasuk di pesisir pulau Jawa). Kedua, pola dialog seperti yang terjadi di pulau Jawa, khususnya daerah pedalaman dan pusat kraton. Ketiga, pola kombinasi antara integratif dan dialog seperti yang berlaku di Sulawesi dan Indonesia Bagian Timur (Hadi WM, 2006: 19).

Fase-fase masuknya Islam di suatu daerah dapat ditelusuri melalui tinggalan-tinggalan yang ada. Tinggalan-tinggalan itu bisa berupa situs-situs masjid tua, makam-makam penyebar Islam awal, dan tinggalan-tinggalan lain yang berkaitan erat dengan budaya Arab maupun Islam. Salah satu cara menelusuri tinggalan-tinggalan tersebut adalah dengan pendekatan penelitian arkeologi.

Azyumardi Azra dalam kata pengantar Arkeologi Islam Indonesia, sebuah penghargaan untuk Uka Tjandrasasmita mengatakan bahwa arkeologi merupakan salah satu ilmu yang sangat dekat, bahkan lengket dengan sejarah, karena keduanya bertujuan sama: mengungkap kehidupan manusia pada masa lalu (Azra, 2009: ix). Didasarkan pada bukti-bukti arkeologis, penulisan sejarah Islam Indonesia memperoleh pondasi yang kuat untuk menjelaskan masuknya Islam ke Nusantara, terbentuknya watak kosmopolitanisme dan dinamika lokal yang terjadi, sampai berlangsungnya proses akulturasi budaya. Diperkaya oleh khasanah naskah Nusantara yang sangat kaya, arkeologi Islam menjadi suatu bidang kajian yang dapat dipertanggungjawabkan untuk merekonstruksi sejarah umat Islam Indonesia.

Berdasarkan pertimbangan pemikiran di atas, maka penelitian ini mengkaji tentang tinggalantinggalan Islam yang ada di Majene, Sulawesi Barat. Secara spesifik pertanyaan penelitian ini diturunkan dalam pertanyaan: masjid kuna) apa saja yang ada di Majene?, makam penyiar awal agama Islam siapa saja yang ada di Majene?, dan naskah-naskah klasik apa saja yang ada di Majene?

Adapun yang dimaksudkan dengan tinggalan Islam dalam penelitian ini adalah semua peninggalan-peninggalan agama Islam pada masa lampau. Peninggalan-peninggalan itu berupa situssitus dan atau masjid kuno yang diyakini sebagai yang pertama ada, situs-situs makam penyiar awal agama Islam, dan naskah-naskah klasik peninggalan ulama pada masa lampau di Majene, Sulawesi Barat.

Ada dua penelitian yang berkaitan langsung dengan lokasi penelitian ini, yakni penelitian Andi Fatmawati Umar dan penelitian Hasanuddin, keduanya dari Balai Arkeologi Makassar. Andi Fatmawati Umar meneliti kiprah Syekh Abdul Mannan dan transformasi sosial di Banggae, Majene (Umar, 2002: 52-59). Penelitian ini menguraikan berdirinya kerajaan Banggae dan transformasi sosialnya. Penelitian ini berkesimpulan bahwa kehadiran Syekh Abdul Mannan di Banggae mendapat bantuan dan dukungan Raja Banggae. hal ini telah mengubah pola pikir masyarakat dalam menanamkan rasa solidaritas dan semangat kebersamaan. Namun demikian, ada keinginan masyarakat untuk tetap mempertahankan kelangsungan tradisi praislam di dalamnya, terutama oleh para keluarga bangsawan yang bertujuan untuk tetap memperbaiki status sosial mereka. Tradisi praislam secara empirik diwujudkan dalam simbolsimbol maupun praktik keagamaan, seperti praktek pendirian bangunan-bangunan makam yang megah dengan ragam hias serta nisan yang ditempatkan di atas bangunan makam berteras. Ini merupakan simbol yang mungkin terkait dengan legitimasi sosial, kekuasaan politik, dan kultural.

Penelitian Hasanuddin dengan judul Pembuktian Arkeologis Letak Toponim Bekas Kerajaan Balanipa di Polewali Mandar (Hasanuddin, 2005: 65-86). Penelitian ini membahas dan mendeskripsikan serta mengidentifikasi data, seperti data situs Napo (meliputi makam I Manyambungi, makam Pappuangan Napo), situs Samasundu (meliputi bekas rumah Puang di Pangale, makam 
pappuangan di Pangale, sumur pappuangan di Pangale), situs bekas pemukiman pappuangan Todang-Todang, situs Tammejarra, situs gunung Mosso, situs Para, situs atau kampung Majapahit di Labuang. Penelitian in juga memaparkan persebaran situs, evidensi arkeologis dan faktor pemukiman, keletakan astronomis toponim situs kerajaan Balanipa, dan hubungan toponim wilayah kerajaan Balanipa.

Penelitian yang lain, walaupun tidak dilaksanakan di Mandar, Sulawesi Barat, akan tetapi erat kaitannya dengan judul ini, yakni penelitian Muhaeminah yang menemukan situs pulau Barang Lompo berupa kompleks makam kampung Cina, kompleks makam kampung Mandar, kompleks kampung pajala. Selain itu, Muhaiminah juga menemukan naskah Alquran tulisan tangan dan keramik Cina (Muhaeminah. 2005: 87-100).

Dari ketiga tulisan hasil penelitian di atas, terlihat bahwa penelitian tentang tinggalantinggalan keagamaan di Mandar, Sulawesi Barat belum pernah dilakukan. Dua penelitian yang pernah dilakukan di Mandar, tulisan pertama, hanya mengungkap kiprah seorang tokoh penyiar Islam, Syekh Abd. Mannan dan tulisan kedua adalah pembuktian arkeologis letak toponim bekas kerajaan Balanipa. Kedua tulisan tersebut belum menyentuh tinggalan-tinggalan keagamaan berupa masjid tua, makam penyiar awal Islam, dan naskah klasik keagamaan di Majene, Sulawesi Barat.

\section{Kerangka Teori \\ Tinggalan Masjid Tua}

Masjid berasal dari kata sajada-yasjudu yang artinya tempat sujud, suatu bangunan, gedung atau lingkaran yang terpagar sekelilingnya yang didirikan secara khusus sebagai tempat ibadah kepada Allah swt. Karena masjid adalah Baitullah (rumah Allah), maka seorang yang memasukinya disunatkan shalat dua rakaat (shalat tahiyat al masjid). Masjid, selain tempat ibadah (shalat lima waktu, shalat Jumat, shalat Tarwih, dan ibadah lainnya), masjid juga digunakan untuk syiar Islam (pendidikan agama dan kegiatan sosial lainnya yang bersifat sosial). Selain fungsi keagamaan dan fungsi sosial tersebut, lebih jauh masjid berfungsi sebagai lembaga untuk mempererat hubungan dan ikatan jamaah.

Perbedaan arsitektur setiap bangunan seperti masjid dapat dipahami, karena arsitektur menurut Achmad Fanani, mengembangkan dirinya untuk memenuhi kebutuhan fisik dan sekaligus metafisik, memenuhi unsur raga maupun kejiwaan masyarakat. Oleh karena itu, keindahan bentuk arsitektur suatu bangunan sebenarnya menjawab keinginan emosional, intelektual seraya menuntun ke arah perenungan (Fanani, 2009: 3).

Islam yang datang di Indonesia setelah berkembang pesat di dunia Arab. Kedatangan orangorang Arab yang beragama Islam di Indonesia, tidak dapat dipungkiri bahwa kedatangan mereka membawa semua identitas yang ada pada diri mereka. Apalagi mengacu pada aspek geografis Indonesia yang merupakan teritorial yang berada pada garis lalu lintas perdagangan yang sangat ramai sejak dahulu. Memosisikan bangsa ini pada posisi itu merupakan keniscayaan untuk membuka akses masuknya pengaruh global dan modernis. Hal terpenting adalah sikap kritis dan selektif terhadap anasir kebudayaan yang akan memengaruhinya, karena bangsa Indonesia tidak bisa lepas dari proses transformasi, baik melalui labirin akulturasi, penetrasi kebudayaan dan semacamnya. Berbagai hal yang lumrah dan natural acapkali ditemukan dalam proses evolusi sejarah intern serta antar bangsa. Namun bangsa Indonesia dengan sikap selektif mampu melakukan penyaringan secara matang dalam mengakomodasi dan menerima unsur-unsur yang datang disesuaikan dengan kondisi obyektif bangsa Indonesia yang pada akhirnya menghasilkan akulturasi yang harmonis dan serasi serta elegan.

Arsitektur pada masjid-masjid kuna tersebut terdapat perbedaan dan persamaan antara satu dengan yang lainnya, ini dimungkinkan karena budaya lokal turut andil memengaruhinya. Kees van Dijk berpendapat bukan struktur asing yang dibawa ke negeri ini oleh penyebar Islam dari luar, melainkan berasal dari bangunan pribumi kuna yang disesuaikan dengan kebutuhan ibadah orang muslim (Dijk, 2009:59).

Menurut Achmad Fanani justru atribut sekunder kebudayaan Islam inilah yang dijadikan momentum sejarah dalam konteks sosiokultural, telah digubah secara fisik menjadi unsur yang sangat dominan posisinya di dalam memberi kesan kesatuan wilayah budaya Islam (Fanani, 2009:11).

\section{Tinggalan Makam Penyiar Islam}

Salah satu hasil cukup menonjol dari budaya Indonesia masa Islam adalah tipologi dan nisan makam. Sebagai hasil seni rupa Indonesia, arsitektur dan filsafat, yang terdapat pada unsur-unsur pokok nisan-nisan di Indonesia merupakan satu kelanjutan 
dari masa-masa sebelumnya yakni masa prasejarah yang disambung ke masa Hindu dan Islam. Makam atau kompleks makam dapat dikaji dari berbagai kajian. Ada yang mengkaji makam (terutama nisan) berdasarkan tipologi, keletakannya pada suatu bentang alam tertentu, letak geografis, dan bahan. Nisan makam di Indonesia berdasarkan atas tipologinya menurut Hasan Muarif Ambary dapat dibagi menjadi tipe Aceh, tipe Demak-Tralaya, tipe Bugis-Makassar, dan tipe Ternate-Tidore. Berdasarkan keletakannya, ada makam yang terletak di dataran rendah dan dataran tinggi. Sementara itu, berdasarkan letak geografinya, terdapat makam ada yang terletak di daerah pesisir atau pantai dan pedalaman (Ambary, 2001: 17).

\section{Tinggalan Naskah Klasik Keagamaan}

Karya tulis yang dihasilkan oleh masyarakat di Sulawesi disebut Lontaraq. Disebut demikian karena bahan yang dijadikan alat menulis adalah daun lontar (Paeni, 2003: xx). Pohon lontar atau disebut juga pohon siwalan termasuk jenis pohon palem (Latin=Palmyra), lontar merupakan helai daun tetapi karena fungsinya sebagai media tulis, maka digolongkan sebagai kertas (Pudjiastuti, 2006: 36). Pada daun lontar tersebutlah para penulis menuangkan gagasan-gagasannya. Adapun isi lontaraq tersebut sangat beragam. Karya-karya itu berupa silsilah, ramalan-ramalan, petunjuk bercocok tanam, tata niaga, mistik, undang-undang pelayaran, tuntunan keagamaan, undang-undang kenegaraan, perjanjian, berbagai kisah, tasawuf, pengobatan, ilmu persenjataan, metode dan taktik perang, tabiat binatang, arsitektur, dan berbagai salinan buku-buku dari luar.

Hal senada diutarakan Soeratno bahwa naskah-naskah lama banyak menyimpan sejumlah hikmat berupa nilai-nilai luhur warisan nenek moyang bangsa yang sampai sekarang masih relevan dengan kehidupan masyarakatnya (Soeratno, 1996: 22). Dengan demikian, dari tulisan-tulisan ini dapat diperoleh gambaran lebih jelas mengenai alam pikiran, adat istiadat, kepercayaan, dan sistem nilai orang pada zaman lampau, suatu pengertian yang tidak mungkin tercapai jika bahan-bahan keterangan hanya terdiri dari peninggalan material (Ikram, 1987: 3).

\section{METODE PENELITIAN}

Untuk memenuhi data yang diperlukan dalam penelitian ini, maka ditempuh beberapa teknik pengumpulan data, yaitu: ekploratif atau penjajagan
(Tim Peneliti Arkenas, 2008: 14), survey, wawancara, dan dokumentasi. Sebagaimana lazimnya dalam penelitian kualitatif, data-data yang terhimpun secara keseluruhan dianalisis secara deskriptif kualitatif. Karena penelitian ini terdiri atas dua data, yakni data arkeologi dan data naskah keagamaan, maka data arkeologi menggunakan deskripsi umum, yakni tipologi yang meliputi: bentuk, jirat, tata letak, dan lain-lain; dan data naskah klasik keagamaan menggunakan metode kodikologi.

\section{PEMBAHASAN \\ Masjid Tua}

Ada beberapa masjid tua yang diklaim oleh masyarakat di daerah ini. Namun yang paling tua adalah masjid di Salabose. Masjid tua Salabose ini dikenal dengan nama Masjid Purbakala Salabose. Masjid ini masuk dalam situs pubakala. Masjid ini berada di lingkungan Salabose, kelurahan Pangaliali, Kec. Banggae Timur, Majene. Masjid ini didirikan oleh Syekh Abd. Mannan bersama dengan Maraqdia Banggae, I Moro Daetta di Masigi (memerintah 1600-1645 M).

Masjid Purbakala Salabose berbeda dengan masjid-masjid lainnya di Majene, masjid ini masih mempertahankan ciri ke'tua’annya, seperti atapnya yang bertingkat tiga, ada serambi di bagian belakang (timur) dan samping kanan (utara). Ciri ketuaan tersebut sebagaimana yang dikemukakan oleh Uka Tjandrasasmita bahwa dilihat dari sudut arsitektur, mesjid-mesjid kuno di Indonesia menunjukkan kekhasan yang membedakannya dengan arsitektur mesjid-mesjid di negeri-negeri Islam lainnya. Kekhasan gaya arsitektur itu dinyatakan oleh atapnya yang bertingkat 2,3,5, denahnya persegi empat atau bujur sangkar dengan serambi di depan atau di samping, pondasinya yang tinggi (Tjandrasasmita, 2000: 162).

Gambar 1. Masjid Purbakala Salabose, Majene (Foto: Idham)

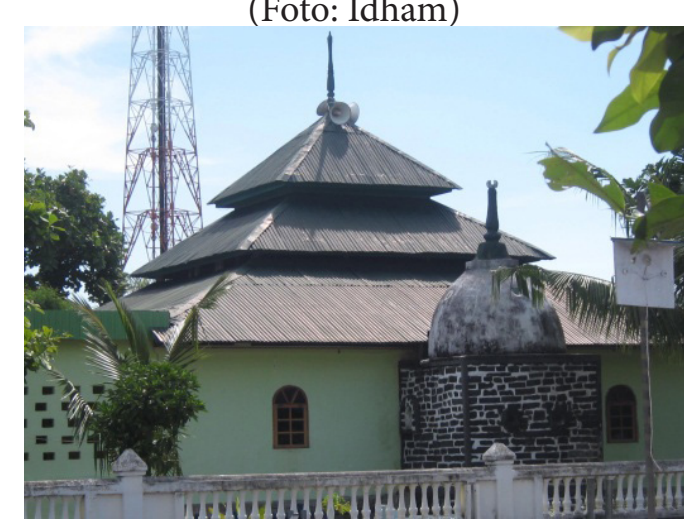


Masjid purbakala Salabose yang termasuk dalam binaan Balai Pelestarian Peninggalan Purbakala pada awalnya hanya beratapkan daun rumbia, namun setelah direnovasi pada tahun 1960-an, atapnya diganti dengan seng. Ruang utama masjid ini adalah 15,20 x 15m dengan empat tiang tengah persegi empat dari kayu sebagai penyanggah, serambi belakang (timur) berukuran $3 \times 15 \mathrm{~m}$, dan serambi bagian kanan (utara) berukuran 6x18,20m.

\section{Makam Penyiar Awal Agama Islam}

Menurut Ahmad (Wawancara di Museum pada tanggal 21 September 2010), pada masa pemerintahan Maraqdia Banggae yang ketiga, Imoro Daetta di Masigi. Daetta di Masigi membawa ke Majene (Banggae) tujuh orang penyiar Islam. Ketujuh ulama penyiar Islam pertama tersebut, hanya empat orang yang dimakamkan di Majene, yakni Syekh Abd. Mannan, Tuan di Colang, Muhammad Ali, dan Tuan Daeng. Selain itu, dua diantaranya yang tidak diketahui identiasnya melanjutkan perjalanan untuk menyiarkan Islam di perbatasan Pangkep dan Barru di Sulawesi Selatan, dan yang satunya lagi diklaim dimakamkan di Polewali Mandar, yakni Tuan di Bulobulo.

Adapun makam penyiar Islam yang dideskripsikan dalam tulisan ini, adalah keempat penyiar Islam yang dimakamkan di Majene, Sulawesi Barat, yaitu:

\section{Makam Abdul Mannan}

Makam Abdul Mannan berada di atas gunung Salabose, tepatnya di lingkungan Salabose Kelurahan Pangaliali kecamatan Banggae Timur kabupaten Majene. Makam ini sudah dimasukkan dalam cagar budaya yang dilindungi. Makam ini berada dalam satu kompleks pemakaman yang baru, dalam artian bahwa makam kuno bercampur dengan pekuburan masyarakat. Makam-makam kuno yang ada di sini dalam keadaan rusak, sementara makam-makam yang baru terlihat terawat dan pada umumnya di marmer. Itulah sebabnya, pemakaman di sini disebut kompleks, yakni "kompleks Makam Syekh Abd. Mannan".
Gambar 2. Kompleks Makam Syekh Abd. Mannan (Foto: Idham)

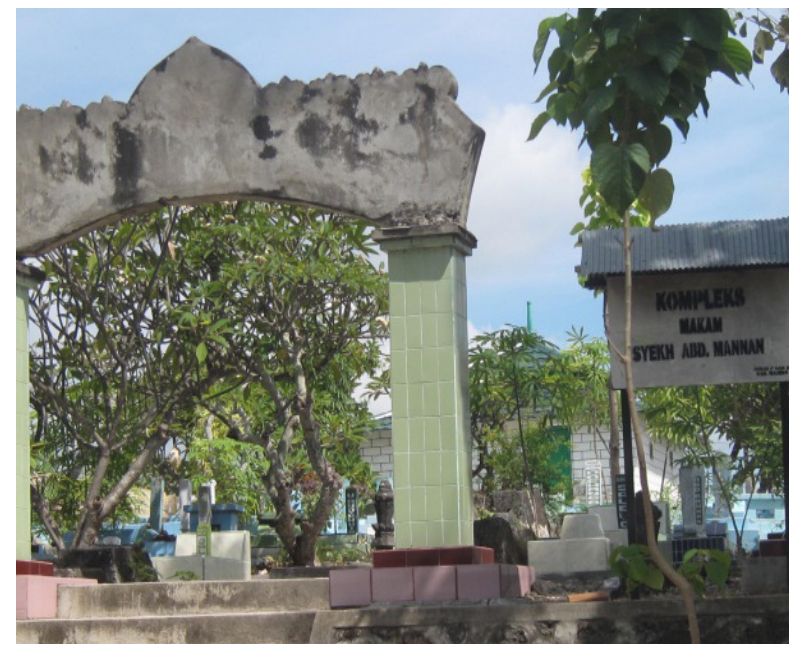

Makam Syekh Abdul Mannan berada di bagian tengah dalam, dekat tebing. Dari luar, makam Syekh Abd. Mannan sudah tampak karena berada dalam bangunan menyerupai masjid. Bangunan tersebut berukuran $5 \times 5$ meter dengan tinggi dinding 1,75 meter dengan lantai marmer berwarna putih. Dinding terbuat dari tembok berbahan baku semen dan bata dengan warna putih bergaris hitam, sementara rangka atap terbuat dari balok kayu dan atapnya adalah seng berwarna hijau.

Untuk masuk ke dalam ruangan makam Tosalama (julukan bagi Syekh Abdul Mannan), peziarah harus membungkukkan badan karena pintunya terbilang pendek, yakni $1,35 \mathrm{~m}$. dari pintu hanya terlihat kelambu putih yang menutupi seluruh ruangan. Untuk melihat makam, kelambu diangkat ke atas. Di dalam kelambu terdapat empat makam, dua di sebelah barat dan satu di sebelah timur. Makam Syekh Abd. Mannan sendiri adalah makam yang terbesar dengan ukuran jirat 142 $\mathrm{cm} \times 246 \mathrm{~cm}$, dengan ketebalan jirat $9 \mathrm{~cm}$. bagian dalam jirat adalah tanah kering dengan dua batu nisan dengan dua buah nisan yang terbuat dari kayu, satu di bagian kepala dengan ukuran tinggi $65 \mathrm{~cm}$ berbentuk segi delapan, dan satu di bagian kaki dengan ukuran tinggi $32 \mathrm{~cm}$ berbentuk pipih berbunga.

\section{Makam Tuan di Colang}

Makam Tuan di Colang berada di lereng bukit, tepatnya di lingkungan Teppo kelurahan Baru, Kecamatan Banggae Timur, Kabupaten Majene. Menuju makam Tuan di Colang, kita akan melalui 
perkampungan dan menyeberangi sungai Teppo. Setelah menyeberang sungai, sudah tidak ada lagi perumahan, yang ada hanyalah kebun dan padang ilalang. Setelah mendaki sekira 500 meter, maka akan tampak pemakaman tua yang tidak terawat. Pemakaman ini oleh warga dijadikan kebun dengan menanam ubi kayu di atas makam tua tersebut.

Tuan di Colang oleh masyarakat setempat diyakini sebagai adik kandung dari Syekh Abdul Mannan. Tidak ada tanda-tanda bahwa di makam ini ada seorang ulama penyiar Islam pertama di Majene, tidak ada papan nama, bahkan makam sudah sangat rusak. Rusaknya makam diakibatkan oleh para penggali (pencari) bahan antik di tahun 1980-an (Darwis, wawancara di Majene pada tanggal 21 November 2010).

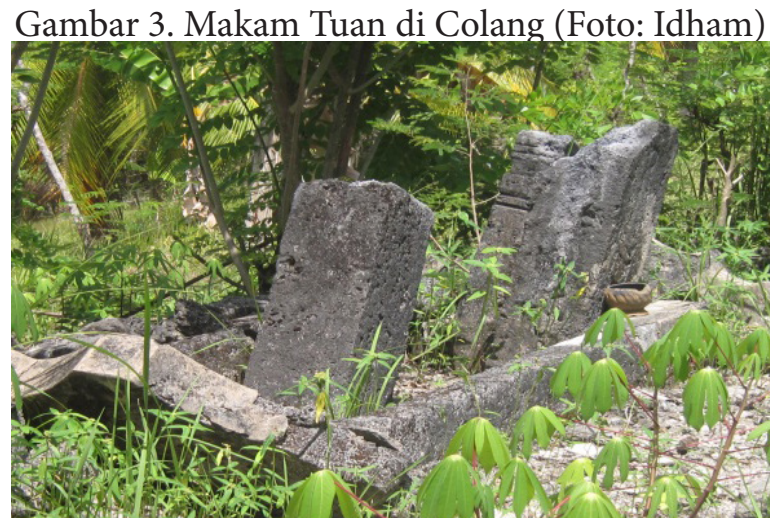

Makam Tuan di Colang jarang dikunjungi oleh para peziarah, tidak sama dengan makam Syekh Abdul Mannan. Kompleks Makam Tuan di Colang tidak ada pembatas area makam, bahkan di atas pemakaman masyarakat menanaminya dengan berbagai macam tanaman, seperti ubi kayu, pisang, dan kelapa. Di samping sebelah timur makam Tuan di Colang hanya disusun batu gunung agar makam tidak terguras tanahnya bila hujan turun. Jirat makam Tuan di Colang berupa batu gunung yang dipahat dan bisa dipasang sambung. Ukuran jiratnya adalah $106 \mathrm{cmx} 180 \mathrm{~cm}$ dengan ketebalan 12 $\mathrm{cm}$. Jirat samping yang membentang utara selatan sudah berpisah dengan jirat sebelah barat-timur. Di dalam jirat terdapat tiga batu nisan. Di bagian kepala dua buah dan di bagian kaki satu buah. Adapun batu nisan di bagian kepala, yang pertama berbentuk segi 8 dengan tinggi $86 \mathrm{~cm}$ dan yang satunya lagi berbentuk empat persegi 26x $26 \mathrm{~cm}$ dengan tinggi 94 $\mathrm{cm}$, adapun di nisan di bagian kaki berbentuk empat persegi $24 \times 24 \mathrm{~cm}$ dengan tinggi $84 \mathrm{~cm}$. semua nisan tersebut terbuat dari batu alam.

\section{Makam Syekh Muhammad Ali (Luaor Kec. Pamboang)}

Makam Syekh Muhammad Ali berada di Luar Kecamatan Pamboang, sekira $15 \mathrm{~km}$ dari kota Majene, sekira 150 meter dari jalan poros MajeneMamuju, belok ke kiri, selanjutnya dengan sedikit pendakian, makam tersebut akan ditemukan yang berada dalam kebun masyarakat. Tampak dari luar tidak menyerupai makam, karena berada dalam sebuah rumah, di depan rumah tersebut terdapat dua buah makam dan sumur mata air. Di dalam rumah dibagi dua, sebagian untuk tempat istirahat peziarah, dan sebagiannya lagi adalah Makam Syekh Muhammad Ali.

Bangunan yang menjadi Makam Syekh Muhammad Ali sudah dipasang Marmer dengan dinding setengah tembok dan setengah bagian atas dari seng dan atap seng. Adapun ukuran bangunan tersebut $4 \times 5 \mathrm{~m}$. Selain makam Syekh Muhammad Ali dalam bangunan ini, juga terdapat satu makam yang menurut masyarakat adalah makam dari anak Syekh Muhammad Ali. Adapun jirat makam syekh Muhammad Ali berupa tembok yang telah dipasang marmer dengan ukuran 90x172 dengan tinggi samping dan $30 \mathrm{~cm}$, bagian kaki $90 \mathrm{~cm}$ dan bagian kepala $50 \mathrm{~cm}$. Di dalam jirat terdapat satu nisan yang berada di bagian kepala. Nisan tersebut terbuat dari kayu berbentuk bulat dengan tinggi $45 \mathrm{~cm}$. makam dari Syekh Muhammad Ali ini dibungkus kelambu warna hijau.

Gambar 4. Makam Syekh Muhammad Ali (Foto: Idham)

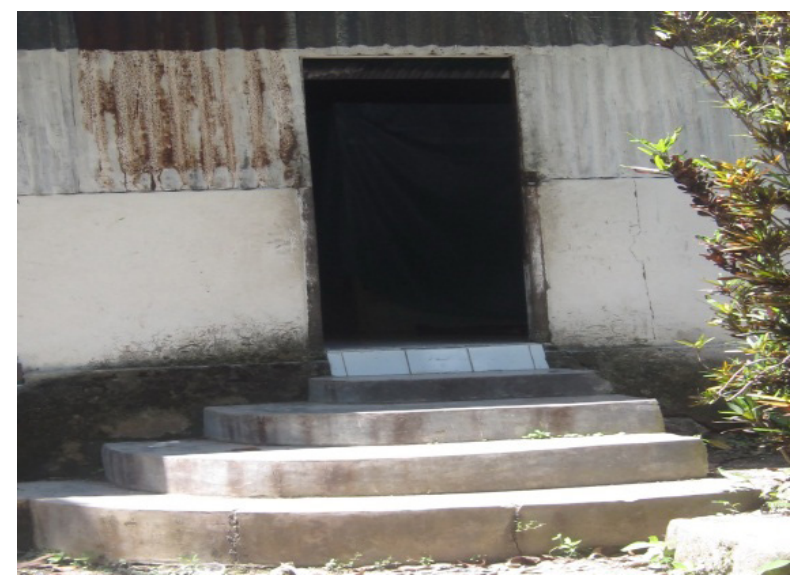

\section{Makam Tuan Daeng}

Makam Tuan Daeng berada di lingkungan Pa’leo Kelurahan Pangaliali, Kecamatan Banggae 
Timur, Majene. Makam ini berada di puncak bukit di depan Kantor Bupati Majene. Dari atas makam, kita dapat melihat panorama kota Majene secara keseluruhan. Makam ini juga berbaur dengan pekuburan yang baru. Meski begitu, pemakaman ini tidak terawat dengan baik sebagaimana makam di sekelilingnya. Pemakaman di sini dikelilingi padang iallang yang lebat. Masuk di pemakaman yang hanya dipagari pohon jarak dan tanaman pagar yang lainnya, tidak tampak ada perbedaan dengan makam-makam yang lain. Yang membedakan makam Tuan Daeng dengan makam yang lain adalah pada makam Tuan Daeng terdapat pohon kuburan yang tinggi yang menandakan bahwa pohon itu sudah sangat tua seiring dengan tuanya kuburan tersebut. Di dalam tebing pohon terdapat batu nisan dalam bentuk batu nisan yang kuno.

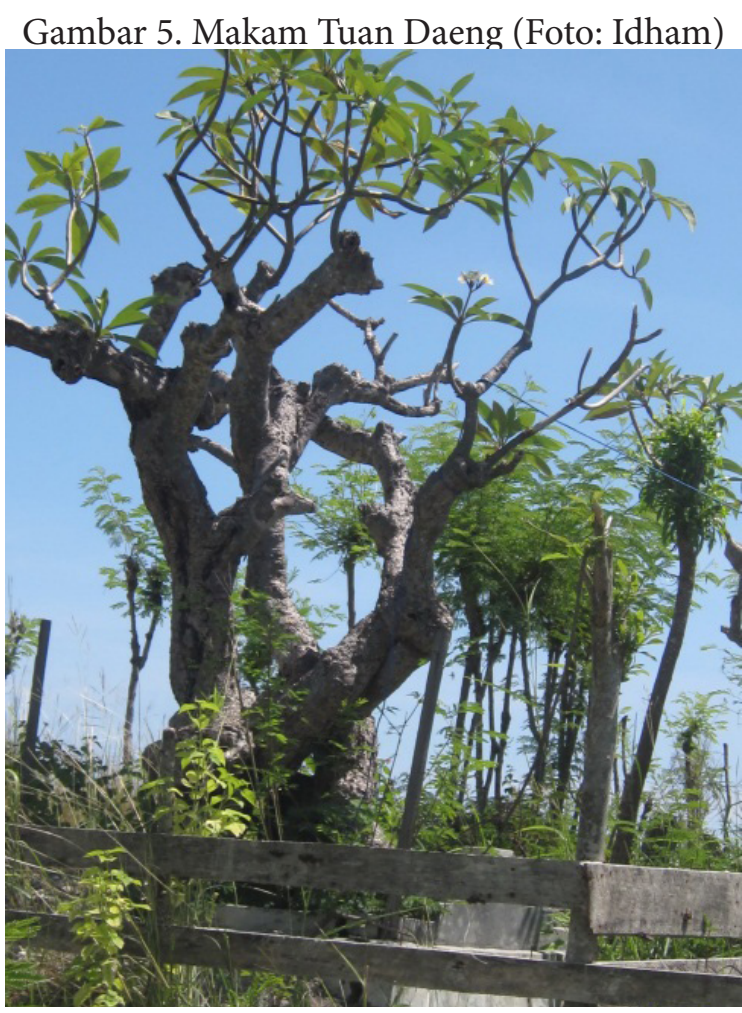

\section{Naskah-Naskah Klasik}

Pada tahun 2009 oleh oleh Balai Penelitian dan Pengembangan Agama Makassar dan Lektur Badan Litbang dan Diklat Agama Kementerian Agama RI telah mengadakan inventarisasi, pemetaan dan digitalisasi naskah klasik di Sulawesi Barat. Hasil inventarisasi menunjukkan bahwa masih banyak naskah-naskah klasik keagamaan yang tersebar di masayarakat. Pemetaan dan digitalisasi itu juga mengecualikan kitab suci dan benda-benda lain yang ada kaitannya dengan tinggalan Islam, seperti kitab suci, dan bendera.

Adapun naskah klasik kitab suci Alquran, dan bendera yang ditemukan pada penelitian ini, yaitu:

\section{Alquran koleksi Muhammad Akil}

Alquran ini disimpan di rumah Muhammad Akil Imam Masjid Purbakala Salabose. Naskah ini tersimpan dalam sebuah kotak kayu jati. Alquran ini tidak diketahui siapa penulisnya. Naskah ini berbentuk buku dengan panjang kertas $16 \mathrm{~cm}$ dan lebar kertas $10 \mathrm{~cm}$. Panjang penulisan teks dari atas ke bawah $11 \mathrm{~cm}$, sedangkan lebar teks dari kanan ke kiri $6 \mathrm{~cm}$ dan jumlah baris dalam satu halaman sebanyak 15 baris.

Naskah ini ditulis pada kertas Eropa dengan tinta berwarna hitam dan merah. Naskah bersampul dengan kulit menyerupai karton warna coklat, dan dijilid dengan benang. Nomor halaman tidak tertulis di bagian atas dan bawah tulisan. Keadaan naskah masih baik, dan tulisan masih jelas terbaca. Isi naskah Alquran lengkap 30 juz, mulai Surah alFatihah sampai Surah al-Nas. Pada bagian akhir naskah terdapat doa khatam Alquran.

\section{Alquran Koleksi Hj. Nuryena}

Naskah ini adalah Alquran tulisan tangan. Penulis, waktu dan tempat penulisan naskah ini tidak diketahui. Naskah ini berbentuk buku dengan panjang kertas $32 \mathrm{~cm}$ dan lebar kertas $22.5 \mathrm{~cm}$. Panjang penulisan teks dari atas ke bawah $24 \mathrm{~cm}$, sedangkan lebar teks dari kanan ke kiri $13 \mathrm{~cm}$. Tebal naskah 610 halaman dan jumlah baris dalam satu halaman sebanyak 15 baris.

Naskah ini ditulis pada kertas Eropa dengan tinta berwarna hitam, hijau dan merah. Naskah bersampul dengan karton warna merah, dan dijilid dengan benang. Nomor halaman tidak tertulis di bagian atas dan bawah tulisan. Keadaan naskah masih baik, dan tulisan masih jelas terbaca. Isi naskah Alquran lengkap 30 juz, mulai Surah alFatihah sampai Surah al-Nas.

\section{Alquran koleksi Sofyan Mubarak}

Naskah Alquran tulisan tangan ini adalah milik Sofyan Mubarak beralamat di Banggae. Naskah berbentuk buku dengan panjang kertas 45 $\mathrm{cm}$ dan lebar kertas $28 \mathrm{~cm}$ tersimpan dalam sebuah kotak kayu jati. Panjang penulisan teks dari atas ke bawah $41 \mathrm{~cm}$, sedangkan lebar teks dari kanan ke kiri $18 \mathrm{~cm}$ dan jumlah baris dalam satu halaman sebanyak 15 baris. 
Naskah ini ditulis pada kertas Eropa dengan tinta berwarna hitam dan merah. Naskah bersampul dengan karton warna merah, dan dijilid dengan benang. Nomor halaman tidak tertulis di bagian atas dan bawah tulisan. Keadaan naskah masih baik, dan tulisan masih jelas terbaca. Isi naskah Alquran tidak lengkap 30 juz, hanya memuat Surah al-Fatihah sampai Surah al-Mu'min.

\section{Naskah khutbah di Kabiraan, Malunda}

Naskah ini diberi judul dengan Khutbah Hari Raya Idul Fitri. Pemberian judul tersebut berdasarkan teks khutbah pertama dan kedua yang dimulai dengan kalimat takbir, walaupun pada judul disebutkan khutbah bulan Ramadhan. Penulis, waktu dan tempat penulisan naskah ini tidak diketahui. Naskah berbentuk lembaran memanjang, dengan panjang kertas $192 \mathrm{~cm}$ dan lebar kertas 22 $\mathrm{cm}$. Lembaran panjang tersebut terdiri atas 2 lembar kertas yang disambung. Untuk menyambung lembaran kertas itu digunakan benang dengan dua buah jahitan pada sambungan kertas, kedua kertas yang disambung tersebut berbeda jenis kertasnya.

Panjang penulisan teks pada halaman depan dari atas ke bawah $114 \mathrm{~cm}$, sedangkan lebar teks dari kanan ke kiri $16 \mathrm{~cm}$. Tebal naskah dua halaman, terdiri atas halaman depan dan halaman belakang. Tulisan hanya terdapat pada halaman depan. Jumlah baris pada halaman depan sebanyak 88 baris. Teks naskah ditulis dengan huruf Arab menggunakan bahasa Arab.

Naskah ini ditulis pada kertas berserat dengan tinta berwarna hitam dan merah. Naskah tidak bersampul, tapi naskah itu digulung kemudian disimpan dalam bambu, nomor halaman tidak tertulis, baik bagian atas maupun bagian bawah tulisan. Keadaan naskah sudah rusak, terutama di bagian pinggir kertas, namun tulisan masih jelas terbaca.

Naskah merupakan khutbah hari raya. Khutbah ini terdiri atas dua bagian, khutbah pertama dan khutbah kedua. Khutbah pertama berisi takbir, puji-pujian kepada Allah, syahadat, shalawat kepada nabi, wasiat bertakwa kepada Allah, ayat dan hadis Nabi berkaitan dengan ibadah puasa, dan doa. Khutbah kedua berisi takbir, pujipujian kepada Allah, syahadat, shalawat kepada Nabi Muhammad saw, dan doa.

Namun ada yang menarik dari naskah ini, yakni bagian atas naskah terdapat gambar atau lukisan perempuan dari etnis cina, juga hiasanhiasan binatang seperti rusa dan naga.
Gambar 6. Bagian atas Naskah Khutbah dan tempat peyimpanannya di Kabiraan, Malunda Majene. (Foto: Idham)

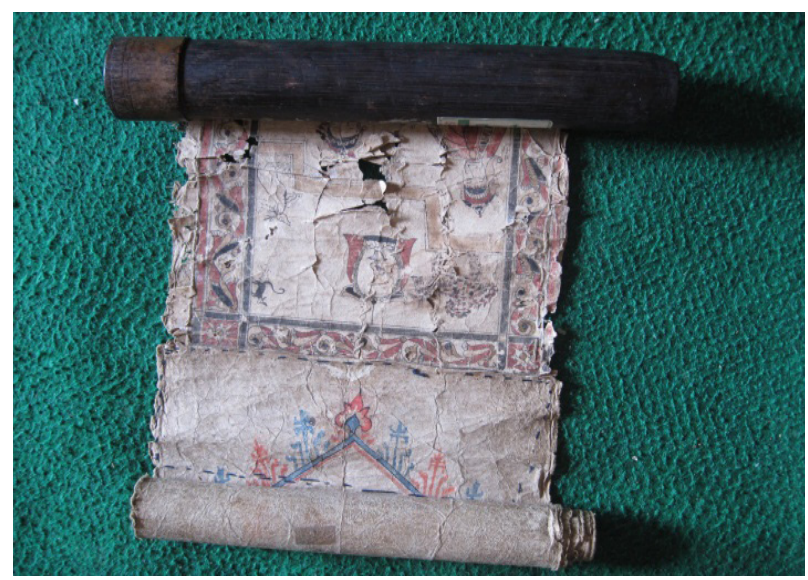

\section{Bendera "I Macang".}

Bendera ini bernama "Bendera I Macang" dengan panjang $227 \mathrm{~cm}$ dan lebar $120 \mathrm{~cm}$. Bendera ini sangat dikeramatkan oleh penduduk setempat, dan hanya bisa dibuka pada hari-hari tertentu. Bendera disimpan di rumah Saharang di Salabose. Bendera berwarna kuning dengan blis warna merah dipinggiranya tersimpan di dalam sebuah kotak kayu jati. Pada bagian tengah terdapat gambar orang memengang pedang di atas seekor binatang (macan). Selain gambar orang bepedang, di empat sudutnya terdapat tulisan Arab dengan nama empat malaikat, yakni Israfil, Jibril, Mikail, dan Israil. Di antara nama-nama malaikat tertulis dengan huruf Arab nama para sahabat Nabi (Abu Bakar, Umar, Usman, dan Ali).

Gambar 7. Bendera "I Macang" di Salabose (Foto: Idham)

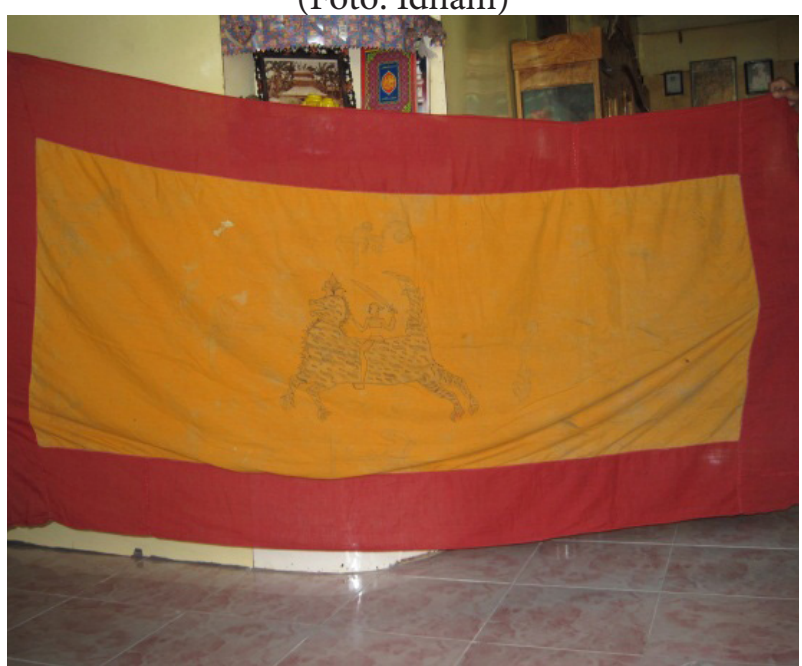




\section{PENUTUP}

Berdasarkan pembahasan di atas, maka penelitian ini berkesimpulan bahwa tinggalantinggalan Islam di Majene Sulawesi Barat bahwa situs rumah ibadah (masjid tua) yang diketemukan di Majene, Sulawesi Barat adalah masjid Purbakala di Salabose yang didirikan oleh Syekh Abd. Mannan bersama Maraqdia Banggae ketiga, I Moro Daetta di Masigi.

Situs makam penyiar awal agama Islam yang sempat didata adalah empat penyiar Islam Pertama di Majene, Sulawesi Barat yakni: Syekh Abd. Mannan, Tuan di Colang, Syekh Muhammad Ali, dan Tuan Daeng. Naskah-naskah klasik yang ditemukan di Majene Majene, Sulawesi Barat berupa tiga buah naskah klasik berupa Alquran tulisan tangan, satu buah khutbah, dan satu buah bendera.

\section{Ucapan Terima Kasih}

Penelitian ini dibiayai oleh DIPA Lektur dan Khazanah Keagamaan Badan Litbang dan Diklat Kementerian Agama RI, bagian Penelitian Kompetitif Tahun Anggaran 2010. Ucapan terima kasih diperuntukkan kepada Kepala Kapus Lektur dan Khazanah Keagamaan Badan Litbang dan Diklat Kementerian Agama RI yang telah mengikutkan saya dalam penelitian ini. Selain itu, ucapan terima kasih kepada kepala Balai Penelitian dan Pengembangan Agama Makassar yang telah memberikan izin dalam penelitian ini, serta ucapan terima kasih kepada Kepala Museum Mandar Majene, aparat pemerintah, serta semua informan yang telah memberikan data-data dalam penelitian ini; juga ucapan terima kasih kepada rekan sejawat yang telah mendukung penelitian ini, Juga kepada redaksi Jurnal Alqalam yang telah memuat tulisan ini. Penulis sangat mengapresiasi setiap kritik, saran, dan diskusi mengenai isi tulisan ini.

\section{DAFTAR PUSTAKA}

Buku:

Ambary, Hasan Muarif. 2001. Menemukan Peradaban Jejak Arkeologis dan Historis Islam Indonesia. Jakarta: Wacana Ilmu.

Azra, Azyumardi. 2009. Arkeologi Islam Indonesia: Sebuah Penghargaan untuk Uka Tjandrasasmita.dalam kata pengantar buku Arkeologi Islam Nusantara yang ditulis oleh Uka Tjandrasasmita. Jakarta: Gramedia.
Dijk, Kees van. 2009. Perubahan Kontur Masjid. Dalam Peter J.M. Nas. Masa Lalu dalam Masa Kini Arsitektur di Indonesia. Jakarta: Gramedia.

Fanani, Achmad. 2009. Arsitektur Masjid: Dilengkapi Dengan Foto dan Ilustrasi. Yogyakarta: Benteng.

Hadi WM, Abdul. 2006. Majalah Suara Muhammadiyah.Jakarta:PP Muhammadiyah.

Hasanuddin. 2005. Pembuktian Arkeologis letak toponim bekas kerajaan Balanipa di Polewali Mandar. dalam "Walannae" Jurnal Arkeologi Sulawesi Selatan dan Tenggara, Vol. VIII. No. 12. Tahun 2002. Makassar: Balai Arkeologi Makassar dibawah pengayoman Pusat Penelitian dan Pengembangan Arkeologi Nasional.

Ikram, Achadiati. 1987. Kegiatan Filologi di Indonesia. Makalah dibacakan pada Penataran Filologi Tahap I Kerjasama LERES IAIN Sunan Kalijaga - Fakultas Sastra UGM.

Muhaeminah. 2005. Tinggalan Masa Islam di Pulau Barang Lompo Makassar: Analisis Hasil Survey Arkeologi. dalam "Walannae" Jurnal Arkeologi Sulawesi Selatan dan Tenggara, Vol. VIII. No. 12. Tahun 2002. Makassar: Balai Arkeologi Makassar dibawah pengayoman Pusat Penelitian dan Pengembangan Arkeologi Nasional.

Paeni, Mukhlis, dkk, 2003. Katalog Induk NaskahNaskah Nusantara Sulawesi Selatan. Jakarta: Proyek Pemasyarakatan dan Desiminasi Kearsipan Nasional Arsip Nasional Republik Indonesia.

Pudjiastuti, Titik. 2006. Naskah dan Studi Naskah Sebuah Antologi. Bogor: Akademia.

Sewang, Ahmad, M. 2005. Islamisasi Kerajaan Gowa (Abad XVI-XVII). Jakarta: Yayasan Obor.

Soeratno, Siti Chamamah. 1996. Naskah Lama dan Relevansinya Dengan Masa Kini. Makalah: Simposium Tradisi Tulis Indonesia.

Tim Peneliti Arkenas. 2008. Metode Penelitian Arkeologi. Jakarta: Pusat Penelitian dan Pengembangan Arkeologi Nasional Badan Pengembangan Sumberdaya Kebudayaan dan Pariwisata Departeman Kebudayaan dan Pariwisata.

Tjandrasasmita, Uka. 2000. Pertumbuhan dan Perkembangan Kota-Kota Muslim di Indonesia Dari Abad XIII sampai XVIII Masehi. Kudus: Menara Kudis. 
Umar, Andi Fatmawati. 2002. Kiprah Syekh Abd. Mannan dan Transformasi Sosial di Banggae, Majene. dalam "Walannae" Jurnal Arkeologi Sulawesi Selatan dan Tenggara, Vol. V. No.
8 Juni 2002. Makassar: Balai Arkeologi Makassar dibawah pengayoman Pusat Penelitian Arkeologi. 